\title{
Rubber Agriculture Tapanuli in the Malaise Era, 1929 - 1939
}

\author{
Edi Sumarno', Junita Setiana Ginting $^{1}$, Nina Karina ${ }^{1}$, M. Azis Rizky Lubis ${ }^{2}$ \\ ${ }^{1}$ Department of History, Faculty of Cultural Science, University of Sumatera Utara, Indonesia \\ ${ }^{2}$ Post Graduate Student of Department of History, Faculty of Cultural Science, University of Sumatera Utara, \\ Indonesia \\ edisumarno64@gmail.com
}

\begin{abstract}
Entering the early 1930s, people's purchasing power has decreased due to the sluggish world economy. This event was later called "The Great Depression" or better known as "Malaise". This decline also occurred in the automotive industry sector which uses a lot of processed rubber as a supporting component. Reduction of the amount of production in the automotive industry then results in reduced absorption of processed rubber. At the same time, the production of rubber precisely increased. As a result, the price of rubber has dropped dramatically. This condition has certainly hit rubber producers. Including smallholder rubber farmers in Tapanuli who also felt the impact of the economic crisis. This paper discusses the condition of smallholder rubber farming in Tapanuli during the malaise. The discussion starts from the situation of smallholder rubber farming before the malaise, continued with the economic depression and its impact on rubber prices, the policy of production restriction by the Dutch East Indies Government and its application, to the impact on rubber farmers in the region. From the results of this study, it can be said that smallholder rubber farmers in Tapanuli were also affected by the "malaise" but the impact was not significant because the community did not adopt a monoculture pattern.
\end{abstract}

Keywords

people's rubber

farming; Tapanuli

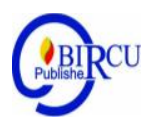

\section{Introduction}

The collapse of stock prices on the Wall Street, New York in October 1929 became one of the triggers in accelerating the occurrence of a major depression which then impacted on the decline of the world economy. This event not only had an impact on the collapse of large industries, but also had an impact on the collapse of small industries or plantations owned by the community, both in developed countries, or developing countries.

In the management of rubber plantations, the aspect of tapping by slicing the skin so that the sap dripping as production is a major component. In other words, tapping done for more than 20 years on plants requires an approach based on agronomic aspects, engineering aspects, and planning aspects and crop management. These things become a priority so that in addition to obtain the sustainable production, high production (in the form of $\mathrm{g} /$ tapping / plant) is also produced. In short, by planting superior clones that do not accompany the aforementioned aspects, rubber production remains low due to the absence of integrated tapping technology (tapping system, tapping frequency, the use of appropriate tools, the use of stimulants, etc.) (Hutapea, et al, (2019).

This impact is then increasingly felt by countries producing primary goods that sell their commodities at very low prices which then impact on the cessation of investment activities in the countries producing these primary goods. To avoid further adverse effects, 
some countries adopt policies economies, such as Britain which released the gold standard, and Japan then devalued the yen. ${ }^{1}$

The Netherlands, which became the ruler of the Dutch East Indies as well as being a producer country, was reluctant to take policy to get out of this difficult situation. The Dutch East Indies refused to devaluate the gulden currency ${ }^{2}$, thereby making the export value lower than the import value. The planters in the Indies were more shocking. Increasing the amount of production in order to maintain income stability was preferred, despite the fact that the price of estate crops fell sharply in 1929 and lasted until 1932, until prices actually dropped in $1933 .^{3}$

Even worse, up to 1937, the Dutch East Indies Government still maintained financial policies that were based on the gold standard, even though this policy had been abandoned for most of the countries affected by the malaise. Production is very worrying, thus further extending the depression period for the Netherlands East Indies itself. ${ }^{4}$

One of the areas of the Dutch East Indies that was affected by the malaise was Tapanuli. As an area that manufactures processed rubber, Tapanuli became one of the areas supplying raw materials to the world industry, especially the automotive industry. Thus, automatically, both plantation and plantation companies in property by the people will receive the effects of this economic depression. This research will only focus on smallholder rubber farming, so that the formulation of the problem starts from the situation of smallholder rubber farming before the malaise, continued with the occurrence of economic depression and its impact on rubber prices, the policy of production restriction by the Dutch East Indies Government and its application, up to its impact on rubber farmers in the region.

\section{Research Method}

This study uses primary and secondary data collection techniques obtained through library studies to institutions that are considered competent, such as the National Library of the Republic of Indonesia and the National Archives of the Republic of Indonesia to collect archives, books, and other forms of publication that are in line with the purpose of this study. After the data is obtained, the next process is to verify the data obtained, and then interpret it into writing.

\section{Discussion}

\subsection{Smallholder Rubber Farming in Tapanuli before Malaise}

Before the great depression hit countries in the world, rubber planting activities carried out by the people in Tapanuli looked normal. As usual, the increase in production and the development of the number of rubber trees was extraordinary, so meaningful. The people in

\footnotetext{
${ }^{1}$ Heaton, H., Economic History of Europe. New York: Harper \& Brothers. 1936

${ }^{2}$ Diska Meizi Arinda, Ufi Saraswati, Abdul Muntholib. Krisis Ekonomi di Banyumas 1930-1935 Sampai Perpindahan Pusat Pemerintahan dari Banyumas ke Purwokerto Tahun 1937.Journal of Indonesian History 6 (1) (2017).p 16

${ }^{3}$ Furnivall, J.S., Netherlands India: A Study Of Plural Economy. Cambridge: The University Press. 1944

4 PADMO, Soegijanto. DEPRESI 1930-AN DAN DAMPAKNYA TERHADAP HINDIA BELANDA. Humaniora, [S.1.], n. 2, june 2013. ISSN 2302-9269. Available at: <https://jurnal.ugm.ac.id/jurnalhumaniora/article/view/2159/1939>. Date accessed: 02 nov. 2019. /*doi:http://dx.doi.org/10.22146/jh.2159. */ doi:https://doi.org/10.22146/jh.2159, p. 150
} 
Tapanuli are so focused on making a profit from rubber latex in order to increase their financial coffers or improve their daily lives.

Starting from 1922 until 1926, the amount of Tapanuli people's rubber exports increased. The increase in the number of exports was triggered by a growing industry in Europe and America that many use rubber as industrial preparations, so that the price of rubber on international markets has increased. ${ }^{5}$ The increase in prices on the international market certainly made people more eager to cultivate rubber plants. Until 1924, rubber trees in Tapanuli amounted to 11,040,000 rubber tree trunks. This amount is calculated based on rubber growing areas in Tapanuli, including (Sibolga, Angkola, Batang Toru, Sipirok, Natal and Batang Natal, Nopan City, Panyabungan, Muara Sipongi, Tarutung and Pahae), where the area has as many trees 3,850,000 rubber tree trunks. ${ }^{6}$ The number is indeed lower when compared to the Padang Lawas Onderafdeeling area which has a total of 7,179,000 trees. ${ }^{7}$

In 1922 the total export of Tapanuli people's rubber amounted to 1,703 tons. The following year, total exports of Tapanuli people's rubber increased, at least, there were 1,025 tons which increased. In 1923, Tapanuli people's rubber exports became 2,728 tons. In the following years, exports of smallholder rubber in Tapanuli increased, namely in 1924 amounting to 3,967 tons, in 1925 there were 3,528 tons, and in 1926 there were 3,820 tons. ${ }^{8}$

In 1927, Tapanuli people's rubber exports were still relatively high, namely 3,563 tons. The decline occurred in 1928 when a regulation was issued regarding the types of processed rubber which were divided into 3 types which took effect on January 1. Total production at that time amounted to 2,236 tons. ${ }^{9}$ Exports returned vigorously in 1929 with a total export of 3,389 tons, with an average of 282 tons per month each. ${ }^{10}$

The increase in exports that occurred from 1922 to 1927 was a result of the adoption of the Stevenson's Scheme by the British to all of its colonies. The Netherlands and its colonies who did not follow these rules then benefited from the British attitude of reducing the amount of production in order to reduce the price of rubber to improve. In these years, the Tapanuli people felt the benefits of rubber plants, after the first decade of the 20th century there was a price boom could feel it.

\subsection{Malaise and Production Restrictions Policy}

The occurrence of a major depression that began in 1929 made the economic situation of the countries in the world turbulent. This situation was clearly unfavorable for developed countries, but also countries that were crawling to develop. Malise then had an impact such as the collapse of prices and commodity demand, the emergence of problems in the cultivation of commercial crops, especially rubber and sugar, financial crisis and declining levels of

\footnotetext{
${ }^{5}$ Dari data yang sama, disebutkan juga bahwa ekspor tahun 1922 berjumlah 1000 ton, 1923 berjumlah 1.963 ton, 1924 berjumlah 3.528 ton, 1925 berjumlah 3.778 ton, dan 1926 berjumlah 4.546 ton. Data dikompilasi dari Verslag van De “Handelsvereeniging te Medan” tahun 1924 - 1927, p. 82, 62, 120, and 122

${ }^{6}$ Carlton P. Brook dan H.W.J. Dofegnies, De Bevolkingsrubbercultuur in Nederlandsch- Indië, V. Tapanoeli en Sumatra's Westkust, Weltevreden: Landsdrukkerij, 1926, p.40

${ }^{7}$ MvOOnderafdeeling Padang Lawas, P. M. Vissers, 1925. Tanpa Halaman

${ }^{8}$ Loc. Cit

9 Third Report on Native Rubber, dalam “The Bulletin Rubber Growers Association”, September 1929, p. 635

${ }^{10}$ Fourth Report on Native Rubber Cultivation, dalam “The Bulletin Rubber Growers Association”, Mei 1930,p. 243-244.
} 
employment opportunities, community income and purchasing power of the community itself. ${ }^{11}$

In the early days of the malaise, the price of rubber greatly fell, ie only 30 cents for every half kilogram, even in August only 25 cents for each kilogram. This then made the export of Tapanuli rubber sluggish, only 2,500 tons in $1930 .{ }^{12}$ The decline also occurred in 1931, the total exports of smallholder rubber in Tapanuli amounted to 1,702 tons. $^{13}$ In 1932 , the number of smallholder rubber exports actually plummeted. Noted, throughout 1932, total exports were only 293 tons. ${ }^{14}$ In addition to the economic depression that caused the automotive industry to decline in America and Europe, the abolition of Stevenson's Scheme in 1928 triggered overproduction, so that industrial countries were unable to accommodate existing production. ${ }^{15}$

The sluggishness of rubber export activities then ended in 1933, where this then continued in 1934 because the amount of Tapanuli people's rubber exports then gradually improved until the first week in May. The decline has occurred since the start of a government meeting of various rubber producers in the world incorporated into IRRA (International Rubber Regulation Agreement) such as the United Kingdom, the Netherlands and France. The meeting discussed the regulation of production and export of rubber from production areas in response to the impact of Stevenson's Scheme revoked on 1928. The reason for this meeting was to maintain the world's rubber supply so that it could be controlled in accordance with market demands and obtain a fair price so that it benefited producers from rubber producers. This rule came to be known as rubber restrictions. By the Dutch government, for smallholder rubber, a special export tax was imposed on dry rubber exports in accordance with price fluctuations. This came into force since June 1, $1934 .^{16}$

Almost throughout 1934 until the first quarter of 1935, rubber prices still declined. In October 1934, exports of dry rubber were then divided into 2 groups, namely groups 1a and 1b. For 1a consists of blankets and sheets that are machined and not rotated by humans, while $1 \mathrm{~b}$ consists of all types of sheets that are viewed based on quality, including width and thickness which must reach $30 \mathrm{~mm} .{ }^{17}$

The first quarter of 1935, rubber trading activity still looks quiet. This is because the rubber producers are busy with the processing of production permits that have been enacted on January 1, 1935. April 1935. People seem to favor individual restrictions rather than special excise exports. Only in Padang Lawas is not the case, people there prefer special excise exports over individual restriction.

In individual restrictions, trees that are tapped with those that are not tapped will be recorded. This data collection aims to determine how many quotas of trees are allowed to be

\footnotetext{
${ }^{11}$ PADMO, Soegijanto. DEPRESI 1930-AN DAN DAMPAKNYA TERHADAP HINDIA BELANDA. Humaniora, [S.1.], n. 2, june 2013. ISSN 2302-9269. Available at: <https://jurnal.ugm.ac.id/jurnalhumaniora/article/view/2159/1939>. Date accessed: 02 nov. 2019. /*doi:http://dx.doi.org/10.22146/jh.2159. */ doi:https://doi.org/10.22146/jh.2159, p. 148

${ }^{12}$ Third Report on Native Rubber, Op.Cit, p. 645

${ }^{13}$ Ninth Report on Native Rubber Cultivation, dalam “The Bulletin Rubber Growers Association”. April 1932, p. 223

${ }^{14}$ Twelfth Report on Native Rubber Cultivation, dalam “The Bulletin Rubber Growers Associationa”, Januari 1933, pp. 56

15 Edi Sumarno, "Perkebunan Karet Rakyat di Sumatera Timur, 1863-1942”, dalam “Tesis”. Yogyakarta:

Program Pasca Sarjana Universitas Gajah mada, 1998, p. 116

${ }^{16}$ bid, p. 119

17 Twenty-first Report on Native Rubber Cultivation, dalam “The Bulletin Rubber Growers Association”, April 1935 , p. 286
} 
tapped. This quota is divided into two parts, namely the Tapanuli basic quota, and the local quota that applies to the regions. In the data collection, it was found that in 1935 the number of trees tapped was 10,264,762 trees, while those that were not tapped were 6,480,659. From this amount, it was found that the Tapanuli quota was $0.35 \%$, while for the local quota it was $3.38 \% .^{18}$

The use of coupons in selling rubber production turned out to be very profitable. This coupon acted as a legitimate tool that seemed to imply that the rubber that was sold did not need to be doubted because it had been registered with the Dutch East Indies government. The results began from the second quarter until the end of 1935, tapping activities resumed because rubber prices were starting to improve. The total export of rubber smallholders in Tapanuli in 1935 was 2,413 tons from 2,579 tons of quota given. ${ }^{19}$

In 1936, the price of rubber using coupons and not using coupons fluctuated, especially for the type of dry rubber sheety crepe, which became the mainstay of Tapanuli because of their high quality. However, sales using coupons and sales without coupons had different prices, even the price difference between using a coupon by not using a coupon can get very far. Of course it will be more expensive to use a coupon. Noted, throughout 1936, the most expensive price was $391 / 4$ cents per kilogram, and for those who did not use coupons only 8 to $81 / 2$ cents per kilogram. This is what sometimes makes traders prefer to only sell their coupons only, without the results of their production.

In 1936, a total production of 5,500 tons. ${ }^{20}$ Rubber prices rose again in 1937. In that year, the highest price was recorded at 66 to 70 cents per kilograms for those using coupons. Exports in 1937 were 8,193 tons. The increase in production was triggered by increasingly expensive prices, especially in the second and third quarters where the price of rubber without a coupon increased. ${ }^{21}$

Rubber tapping activities began to decline in 1938. In that year, smallholder rubber exports decreased by $50 \%$ when compared to $1937 .{ }^{22}$ That means, exports of smallholder rubber were only 4,044 tons. This decline occurred in the first 5 months due to low selling prices rubber without the use of coupons, so that buying and selling activities were slightly disrupted. Exports increased again in the third quarter. This increase was not caused by the high price of rubber, but the public pursued production to be able to calmly welcome the month of Ramadan. ${ }^{23}$

Increasing the price of rubber both using coupons and those not using coupons made the rubber tapping activity vigorous again. In 1939, the total exports of dry smallholder rubber was equal to 4,196 tons. This number increased slightly from 1938 which experienced a decrease in the quantity and quality of production. ${ }^{24}$ The warming world political conditions made prices even more chaotic, both prices of basic necessities and prices of industrial needs. Sea security as a path for export-import activities began to be threatened when the Second

\footnotetext{
${ }^{18}$ Ibid, p. 172

${ }^{19}$ Twenty-fifth Report on Native Rubber Cultivation, dalam “The Bulletin Rubber Growers Association”, Mei 1936, p. 187

${ }^{20}$ Twenty-ninth Report on Native Rubber Cultivation, dalam “The Bulletin Rubber Growers Association”, Mei 1937, p. 229

${ }^{21}$ Verslag van "De Handelsvereniging te Medan" Over het Jaar 1937, p. 305

${ }^{22}$ Verslag van "De Handelsvereniging te Medan" Over het Jaar 1938, p. 286

${ }^{23}$ Native Rubber Report for Second Half-Year, dalam "The Bulletin Of The Rubber Growers Association", April 1939, p. $237-238$.

${ }^{24}$ Verslag van "De Handelsvereniging te Medan" Over het Jaar 1939, p. 282
} 
World War romance began to be felt in 1940. This led to sluggish rubber tapping and began to really be transferred to other commodities.

\subsection{The attitude of the People's Rubber Farmers over the Lower Rubber Prices Tapanuli}

The price of rubber that is not fixed and always fluctuating becomes a challenge for the people who cultivate it. Large profits will certainly always be overshadowed by losses that are also not small in number. Mainly caused by policies that emerged up to the time of economic depression as it has been since 1929.

During the malaise, rubber and sugar plantations received a very extraordinary impact. Whether it was undertaken by large investors, to the local community. Everything collapsed because the export value of these two commodities was so low. this suffering. Decreased employment opportunities, low income, and low purchasing power of people became a serious problem at that time. ${ }^{25}$

But for the people of Tapanuli, especially those who cultivate rubber plants, the community has its own way of dealing with the problems that occur. In the early days of depression, the community chose to leave their rubber fields and then glanced back at coffee plantations that were previously under-attention because of the high price of rubber. Not to forget, the community also returned to take care of their rice fields to cover daily needs in difficult times. In addition to coffee and rice, the community also planted pepper and coconut to be used as copra. ${ }^{26}$

In the Sibolga and Mandailing Kecil areas, for example, in the second quarter of 1931, community attention towards rice fields and other plantations increased. Communities began to harvest rice fields and gardens planted with other commodities. Although in other areas there are still some who tap the rubber trees, this is done only to prepare the month of Ramadan and fulfill the needs of the Eid al-Fitr. Not only that, there are also people who do wiretapping to pay taxes. ${ }^{27}$

Still in the same year, in the Barus region, the community was getting ready to plant rice in the rice fields they owned. Of course this has an impact on the decline in rubber tree tapping activities. Trees that are considered to be old are then cut down so that people get an empty space to then be planted with food plants around the garden. ${ }^{28}$

The low price of rubber during the fourth quarter of 1932 made tapping activities quiet because farmers assumed they would not benefit. As a result, during the fourth quarter, tappers from Java were unemployed, and some even left the residency because they did not get work. ${ }^{29}$ This then continued in the following years, when workers who were skilled in maintenance and tapping began to diminish. This is actually not a problem for rubber farmers

\footnotetext{
${ }^{25}$ PADMO, Soegijanto. DEPRESI 1930-AN DAN DAMPAKNYA TERHADAP HINDIA BELANDA.

Humaniora, [S.1.], n. 2, june 2013. ISSN 2302-9269. Available at: <https://jurnal.ugm.ac.id/jurnalhumaniora/article/view/2159/1939>. Date accessed: 02 nov. 2019. /*doi:http://dx.doi.org/10.22146/jh.2159. */ doi:https://doi.org/10.22146/jh.2159, p 151.

${ }^{26}$ Fourth Report on Native Rubber Cultivation dalam “The Bulletin Of The Rubber Growers Association”, Mei 1930, pp. 243-244.

${ }^{27}$ Ninth Report on Native Rubber Cultivation dalam "The Bulletin Of The Rubber Growers Association”, April 1932, p. 227

${ }^{28}$ Sixth Report on Native Rubber Cultivation dalam “The Bulletin Of The Rubber Growers Association”, Mei 1931, pp. 237-238.

29 Thirteenth Report on Native Rubber Cultivation dalam “The Bulletin Of The Rubber Growers Association", April 1933, p. 230.
} 
in Tapanuli, because rubber farmers are more optimizing family labor in the process of tapping. There are also those who use local youth who live close to rubber fields. This is done because the Javanese people prefer to return to work on plantations or refuse offers of work because the wages obtained are considered unprofitable. The Nias people who worked on community rubber land in Tapanuli also followed the same footsteps as the Javanese did. The Nias people chose to return to their home regions to work on copra because it was considered to be profitable. ${ }^{30}$

The pattern of community agriculture that is not monoculture makes the Tapanuli people more prepared when facing a depression like this. Apart from being a way out when the price of one commodity goes down, people can work on other commodities that are more profitable. In Tapanuli, when the price of rubber is high, farmers will pay more attention to this tree, so that the community divides their work time by 15 days for rubber plants, and the next 15 days for working on rice fields. Sometimes this can be more so that when the price of rubber is high, the amount of rice imports and other commodities will increase. ${ }^{31}$ This pattern also applies to coffee plants. When rubber prices are high, coffee exports from Tapanuli will decline, whereas if rubber prices decline, coffee exports from Tapanuli will increase. The increase in coffee exports occurred in 1932 until the first quarter of 1933 when the price of rubber was really down. In 1931, the amount of coffee and rubber exports was only $276.7 \mathrm{~kg}$. ${ }^{32}$ The number of Robusta coffee exports will increase while decreasing the price of rubber. The highest coffee export occurred in 1932 where the price of rubber actually fell. In that year, Robusta coffee exports were 2955.4 tons, while rubber exports were only 293.1 tons, or only $10 \%$ of the total coffee exports. ${ }^{33}$

A similar situation also occurs in Padang Lawas Onderafdeeling. The community does not feel a significant influence when the price of rubber decreases. The community divides their busy activities equally between caring for rubber plants with other commodity roses, so that when the price of rubber decreases, the community can utilize other commodities as a livelihood. ${ }^{34}$ In fact, in 1935 , due to the quite large distribution of rubber trees in the region, coupled with the amount of income the community got, the government raised the tax which was originally only $3 \%$ then to $8 \% .^{35}$

From Sumatra In late 1936 until early 1937 in the Sibolga region, the money earned from selling rubber was used to build luxury homes, or to use the money to repair homes that had been aged. The money obtained is also spent to meet the needs of clothing and shelter. ${ }^{36}$ In addition, in the same year, milk, sardines, biscuits and grapes imported from East and West Sumatra increased in number. ${ }^{37}$ This happened because in 1936 and 1937, rubber prices experienced an increase after previously experiencing a decline.

\section{Conclusion}

\footnotetext{
${ }^{30}$ Twenty-ninth Report on Native Rubber Cultivation. Op.Cit, p. 233.

${ }^{31}$ Carlton P. Brook dan H.W.J. Dofegnies, Op.Cit, p. 4

${ }^{32} \mathrm{MvO}$ (Memorie Van Overgave) de Onderafdeeling Padang Lawas, G.W. Van Der Zwalm, 1936, p. 180

${ }^{33}$ Ibid, p. 179.

${ }^{34}$ Loc. Cit.

${ }^{35} \mathrm{MvO}$ (Memorie van Overgave) Onderafdeeling Padang Lawas. 1935, p.27

${ }^{36} \mathrm{MvO}$ (Memorie van Overgave) H. Bartstra, Controleur van Sibolga en Ommelanden, 1 Juni 1935 - 9 Juni 1938, p. 73.

37 Verslag van "De Handelsvereniging te Sibolga" Over het Jaar 1937,p.14
} 
The world economic crisis that began in 1929 had a negative impact on all regions in the world. Especially the areas that became the basis of plantations, both sugar cane plantations and rubber plantations. The Dutch East Indies which is one of the largest rubber producing countries automatically felt the crisis which one of them caused by the collapse of stock prices on the Wall Street, New York in October 1929.

As one of the rubber producers in the Dutch East Indies, Tapanuli also felt the difficulties that occurred during the malaise. But the perceived difficulties did not significantly affect the daily lives of the Tapanuli people. The habits of the people who did not make monoculture farming patterns and chose to make polyculture farming patterns became saviors. For the people especially during times of crisis like this. The Tapanuli people who cultivate rubber plants are not so worried about the crisis because people can use other commodities that have been planted on their land, such as coffee, coconut, rice and pepper. With the planting of other commodities which are no less profitable, the people in Tapanuli have successfully passed the crisis that has taken place throughout the world.

\section{Acknowledgement}

This article couldn't have been possible thanks to funding of "Penelitian TALENTA USU skema Penelitian Dasar" with the contract number 4167/UN5. 1. R/PPM/2019 dated 01 April 2019. We also thanks to Lembaga Penelitan USU which has accommodated this research. Besides that, we also thanks to Arsip Nasional Republik Indonesia because the sources of this article are widely available there.

\section{References}

Arinda, Diska Meizi, Ufi Saraswati, Abdul Muntholib. (2017). Krisis Ekonomi di Banyumas 1930-193. Sampai Perpindahan Pusat Pemerintahan dari Banyumas ke Purwokerto Tahun 1937. Journal of Indonesian History 6 (1).

Brook, Carlton P. and H.W.J. (1926). Dofegnies, De Bevolkingsrubbercultuur in Nederlandsch- Indië, V. Tapanoeli en Sumatra's Westkust, Weltevreden: Landsdrukkerij.

Furnivall, J.S., (1944). Netherlands India: A Study Of Plural Economy. Cambridge: The University Press.

Fourth Report on Native Rubber Cultivation, (1930). in "The Bulletin Rubber Growers Association", May 1930

Heaton, H., (1936). Economic History of Europe. New York: Harper \& Brothers.

Hutapea, S., et al. (2019). Introduction to Application of Rubber Tapping Technology and Its Impact on Production in Mekar Tani Group, Sari Laba Jahe Village, Deli Serdang Regency. Budapest International Research in Exact Sciences (BirEx) Journal, 29-34.

$\mathrm{MvO}$ (Memorie van Overgave). (1925). OnderafdeelingPadang Lawas, P. M. Vissers.

MvO (Memorie van Overgave). 1935 Onderafdeeling Padang Lawas.

$\mathrm{MvO}$ (Memorie van Overgave). (1938). H. Bartstra, Controleur van Sibolga en Ommelanden, 1 June 1935 - 9 Juni

Native Rubber Report for Second Half-Year, (1939). in "The Bulletin Of The Rubber Growers Association”, April

Ninth Report on Native Rubber Cultivation (1932). in "The Bulletin Of The Rubber Growers Association", April 
Padmo, Soegijanto. DEPRESI 1930-AN DAN DAMPAKNYA TERHADAP HINDIA BELANDA.Humaniora, [S.1.], n. 2, June 2013. ISSN 2302-9269. Available at: <https://jurnal.ugm.ac.id/jurnal-humaniora/article/view/2159/1939>. Date accessed: 02 nov. 2019. /*doi:http://dx.doi.org/10.22146/jh.2159. doi:https://doi.org/10.22146/jh.2159.

Sixth Report on Native Rubber Cultivation in "The Bulletin Of The Rubber Growers Association", May 1931

Sumarno, Edi. "Perkebunan Karet Rakyat di Sumatera Timur, 1863-1942", in "Tesis".

Yogyakarta: Program Pasca Sarjana Universitas Gajah mada, 1998.

Third Report on Native Rubber, in "The Bulletin Rubber Growers Association", September 1929.

Thirteenth Report on Native Rubber Cultivation in "The Bulletin Of The Rubber Growers Association", April 1933.

Twelfth Report on Native Rubber Cultivation, (1933). in "The Bulletin Rubber Growers Associationa”, Januari

Twenty-first Report on Native Rubber Cultivation, (1935) in "The Bulletin Rubber Growers Association", April

Twenty-fifth Report on Native Rubber Cultivation, (1936) in "The Bulletin Rubber Growers Association", Mei

Twenty-ninth Report on Native Rubber Cultivation, (1937) in "The Bulletin Rubber Growers Association", Mei

Verslag van. (1927). "De Handelsvereeniging te Medan” tahun 1924 -1927

Verslag van. (1937). "De Handelsvereniging te Medan" Over het Jaar

Verslag van. (1938). "De Handelsvereniging te Medan" Over het Jaar

Verslag van. (1939). "De Handelsvereniging te Medan" Over het Jaar 